Jurnal Pengendalian Pencemaran Lingkungan (JPPL)

Vol.1 No.01 September 2019

\title{
PENGARUH PERBEDAAN BANTUK BAHAN BAKU DAN SUHU GASIFIKASI AMPAS TEBU TERHADAP PRODUKSI HIDROGEN
}

\section{The Effect of Differences of Raw Materials and Temperature Process of Sugar- Cane Bagasse Gasification on Hydrogen Production}

\author{
Shafwan Amrullah ${ }^{1}$, Theresia Evila ${ }^{2}$ \\ ${ }^{1}$ Jurusan Teknologi Industri Pertanian, Universitas Teknologi Sumbawa, Indonesia \\ ${ }^{2}$ Jurusan Teknologi Rekayasa Pengendalian Pencemaran Lingkungan, Politeknik Negeri Cilacap, Indonesia.
}

*Penulis korespondensi. No Tel: 087838700868. Email: shafwan.amrullah@uts.ac.id.

\begin{abstract}
Abstrak
Penggunaan bahan bakar fosil saat ini sangat mengganggu keberlangsungan hidup, terutama berhubungan dengan dampak lingkungan dan ekonomi. Sedangakan kebutuhan anergi dunia terus meningkat. Peningkatan tersebut mencapai $80 \%$ hingga tahun 2040 . Untuk mengatasi permasalahan tersebut, para ilmuan telah mengembangkan teknologi gasifikasi yang dapat meghasilkan bahan bakar sebagai pengganti bahan bakar fosil. Gasifikasi dari biomassa dapat menghasilkan gas sintetik yang lebih ramah lingkungan serta dapat diperbaharui. sehingga Tujuan dari penelitian ini adalah untuk mengetahui pengaruh berbedaan bentuk bahan baku dan suhu terhadap hidrogen yang dihasilkan oleh proses gasifikasi berbahan baku ampas tebu. Penelitian ini dilakukan melalui proses gasifikasi berbahan baku biomassa ampas tebu untuk menghasilkan gas sintetik yang dapat menggantikan bahan bakar fosil. Jenis reaktor yang digunakan adalah reaktor tipe downdraft. Penelitian ini dilakukan dengan proses gasifikasi menggunakan bahan baku ampas tebu berbentuk pellet dengan ukuran diameter dan panjang berturut-turut $6 \mathrm{~mm}$ dan $50 \mathrm{~mm}$ dan yang lainnya berbentuk serabut. Gasifikasi dilakukan juga dengan variasi suhu, yaitu 800,950 , dan $1.050^{\circ} \mathrm{C}$. Setelah itu, Gas sintetik yang dihasilkan diuji dengan Gas Chromatography pada tiap variabel sehingga diketahui kadar hidrogennya. Hidrogen yang dihasilkan didifiniskan dalam bentuk produk $\mathrm{H}_{2}, \mathrm{CH}_{4}$, dan nilai hydrogen conversion efficiency. Hasil yang didapatkan memperlihatkan terjadinya peningkatan $\mathrm{H}_{2}, \mathrm{CH}_{4}$, dan hydrogen conversion efficiency dengan adanya peningkatan suhu gasifikasi, baik pada bentuk pellet maupun serabu. Sedangkan untuk perubahan bentuk bahan baku dari pellet ke serabut mengakibatkan penurunan kadar $\mathrm{H} 2, \mathrm{CH} 4$, dan Nilai hydrogen conversion efficiency. Komposisi $\mathrm{H} 2$ yang dihasilkan pada suhu 800,950 , dan $1050^{\circ} \mathrm{C}$ berturut-turut adalah 10,618, 12,080, 11,312\%volume dan 3,025, 2,925, 3,150\%volume. komposisi CH4 untuk bahan baku berbentuk pellet dan serabut pada suhu 800 . 950, dan $1050^{\circ} \mathrm{C}$ berturut-turut adalah 1,040, 2,622, $2,867 \%$ volume dan $0,846,0,856,1,051 \%$ volume. Nilai yang didapatkan tersebut relatif sangat kecil dibandingkan dengan hasil yang didapatkan pada penelitian-penelitian sebelumnya. Nilai hydrogen conversion efficiency untuk bahan baku berbentuk pellet dan serabut pada suhu 800.950 , dan $1050^{\circ} \mathrm{C}$ berturut-turut adalah $1,62 \%, 3,45 \%, 3,91 \%$ dan $1,89 \%, 1,92 \%, 2,32 \%$.
\end{abstract}

Kata kunci: gasifiakasi, downdraf, bentuk bahan, suhu, hydrogen conversion efficiency.

\section{Abstract}

DOI : 10.35970/jppl.v1i1.49

Corresponding Author : shafwan.amrullah@uts.ac.id. 
Jurnal Pengendalian Pencemaran Lingkungan (JPPL)

Vol.1 No.01 September 2019

The use of fossil fuel at this time is very disturbing survival, especially related to environmental and economic impacts. While the needs of world anergy continue to increase. The increase reached 80\% until 2040. To overcome this problem, scientists have developed gasification technology that can produce fuel as a substitute for fossil fuel. Gasification from biomass can produce synthetic gas that is more environmentally friendly and renewable. so the purpose of this study was to determine the effect of different forms of raw material and temperature on hydrogen produced by the gasification process made from sugarcane bagasse. This research was conducted through a process of gasification made from bagasse biomass to produce synthetic gas that can replace fossil fuel. The type of reactor used is downdraft type reactor. This research was carried out by the gasification process using raw material in the form of sugarcane bagasse with diameters and lengths of 6 $\mathrm{mm}$ and $50 \mathrm{~mm}$ respectively and the others in the form of fibers. Gasification is also carried out with variations in temperature, namely 800, 950 and 1,050oC. After that, the synthetic gas produced is tested by Gas Chromatography on each variable so that the hydrogen content is known. The hydrogen produced is defined in the form of H2, CH4 products, and the value of hydrogen conversion efficiency. The results obtained showed an increase in $\mathrm{H} 2, \mathrm{CH} 4$, and hydrogen conversion efficiency with an increase in gasification temperature, both in the form of pellets and ash. As for the change in the form of raw materials from pellets to fibers, it causes a decrease in $\mathrm{H} 2, \mathrm{CH} 4$, and hydrogen conversion efficiency values. H2 compositions produced at temperatures of 800,950 , and $1050^{\circ} \mathrm{C}$ were $10.618,12.080,11.312 \%$ by volume and $3.025,2.925,3.150 \%$ by volume, respectively. CH4 composition for raw materials in the form of pellets and fibers at temperatures of 800,950 , and $1050^{\circ} \mathrm{C}$ were $1.040,2.622,2.867 \%$ by volume and $0.846,0.856,1.051 \%$ by volume, respectively. The value obtained is relatively very small compared to the results obtained in previous studies. The value of hydrogen conversion efficiency for raw materials in the form of pellets and fibers at 800,950 , and $1050^{\circ} \mathrm{C}$ are $1.62 \%, 3.45 \%, 3.91 \%$ and $1.89 \%, 1.92 \%, 2,32 \%$.

Keywords: gasification, downdraft type, material form, temperature, hydrogen conversion efficiency

\section{PENDAHULUAN}

Bahan bakar fosil saat ini semakin menipis, sedangkan kebutuhan akan bahan bakar fosil terus meningkat setiap tahunnya, dan diprediksi kebutuhan akan energi fosil akan mencapai $80 \%$ pada tahun 2040 (Word Energy Outlook, 2013). Selain itu, bahan bakar fosil dapat menyebabkan polusi udara hingga dapat mengganggu kesehatan manusia dan lingkungan. Dengan adanya fenomena tersebut, perlu adanya bahan bakar alternatif yang dapat memenuhi kebutuhan energi sekaligus menciptakan bahan bakar ramah lingkungan. Saat ini telah banyak dikembangkan teknologi yang dapat menjawab persoalan tersebut, ssalah satunya adalah energi yang dihsailkan dari proses pirolisis dan gasifikasi. Namun dilihat dari effisiensi energinya, gasifikasi dengan menggunakan bahan baku biomassa lebih tepat digunakan (Herlambang dkk., 2018).

Biomassa sendiri merupakan sumber energi yang sangat potensial, selain karena sifatnya yang dapat diperbaharui, biomassa juga termasuk dalam kategori carbon neutral. Carbon neutral berarti $\mathrm{CO}_{2}$ yang dihasilkan dari pembakarannya tidak terbuang ke lingkungan, sebab akan digunakan kembali oleh tumbuhan sebagai senyawa untuk fotosintesis (Amrullah dkk., 2017). Ketersiadaan biomassa di Dunia juga cukup besar, yaitu diprediksi dapat digunakan sebagai suplai energi hingga 2050 (Bauen dkk., 2009). Di Indonesia sendiri biomassa sangatlah berlimpah, terutama limbah hasil pabrik gula yang berupa ampas tebu. Dari data yang didapatkan, diperkirakan terdapat ampas tebu sekitar 140 juta ton per tahun yang dihasilkan oleh pabrik gula (BPS-RI, 2012). Ampas tebu tersusun atas 55-60\% serat, 30-35\% pith, 10-15\% tanah, dan bahan terlarut. Secara kimia, ampas tebu terdiri atas $46-47 \%$ selulosa, $24-26 \%$ pentose, $20-21 \%$ lignin, dan $10-15 \%$ unsur

DOI : 10.35970/jppl.v1i1.49

Corresponding Author : shafwan.amrullah@uts.ac.id. 
Jurnal Pengendalian Pencemaran Lingkungan (JPPL)

Vol.1 No.01 September 2019

lainnya. Dari komposisi tersbut dapat dikatakan bahwa, ampas tebu sangat baik untuk dikonversi menjadi bahan bakar terbarukan melalui proses gasifikasi.

Gasifikasi sendiri merupakan teknologi dengan poses termo kimia yang dapat merubah padatan atau cairan yang mengandung karbon, hidrogen, oksigen, dan unsur organikmenjadi produk berbetnuk gas dengan bantuan oksigen terbatas yaitu sekitar 20-40\% (Sarker dkk., 2015). Gasifikasi dapat dijalankan pada suhu sedang $\left(350-400^{\circ} \mathrm{C}\right)$ atau pada suhu tinggi $\left(700-1.000^{\circ} \mathrm{C}\right)$ pada tekanan atmosfer (Fleddmann, 2008 ; Freitas dan Guirardello, 2015). Nilai bakar dari arang yang diperoleh dari hasil gasifikasi sebanding dengan batu bara muda, nilai bakar produk cairan sebanding dengan bahan bakar seperti metanol dan etanol, sedangkan nilai bakar produk gas sebanding dengan nilai bakar gas hasil pembakaran batu bara (Yaman, 2004). Produk yang dihasilkan dari proses gasifikasi tersebut terdiri dari gas $\mathrm{CO}, \mathrm{CO}_{2}, \mathrm{H}_{2}$, dan $\mathrm{CH}_{4}$. Selain itu produk samping juga terbentuk, yaitu berupa sejumlah kecil arang karbon dan abu (Balat dkk., 2009). Dari produk yang dihasilkan tersebut, dapat dilihat bahwa, terbentuknya beberapa gas yang ramah terhadap lingkungan, seperti hidrogen. Sehingga pada penelitian ini akan dilihat seberapa besar produk hidrogen yang akan dihasilkan dari proses gasifikasi biomassa berbahan baku ampas tebu.

Beberapa proses yang terjadi pada gasifikasi dapat dilihat pada persamaan 1 sampai persamaan 7 (Rodregues dkk., 2017). Pada persamaan tersebut dapat dilihat skema yang terjadi di dalam reaktor gasifikasi hingga dihasilkannya produk berupa gas sintetik seperti yang telah dijelaskan di atas. Persamaan 1 sampai 7 terbagi dalam 4 zona utama gasifikasi, yaitu zona proses pengeringan, pirolisis, oksidasi, dan reduksi. Persamaan 1 terjadi pada zona oksidasi. Sedangkan persamaan 2-6 terjadi pada zona reduksi. Zona pengeringan terjadi pada suhu lebih besar dari $150^{\circ} \mathrm{C}$. Zona pirolisis terjadi pada suhu lebih dari $150^{\circ} \mathrm{C}$ dan kurang dari $700^{\circ} \mathrm{C}$. Zona oksidasi terjadi pada suhu lebih besar dari $700^{\circ} \mathrm{C}$ dan kurang dari $1.500^{\circ} \mathrm{C}$. Sedangkan zona reduksi terjadi pada suhu diatas $800^{\circ} \mathrm{C}$ dan kurang dari $1.000^{\circ} \mathrm{C}$ (Rajvanshi, 1986).

a. Carbon oxidation:

$\mathrm{C}+\mathrm{O}_{2} \leftrightarrow \mathrm{CO}_{2} \quad \Delta \mathrm{H}=-393,8 \mathrm{~kJ} / \mathrm{mol}$

b. Boudouard :

$\mathrm{C}_{(s)}+\mathrm{CO}_{2} \leftrightarrow 2 \mathrm{CO} \quad \Delta \mathrm{H}=+172 \mathrm{MJ} / \mathrm{kmol}$

b. Water gas :

$\mathrm{C}_{(s)}+\mathrm{H}_{2} \mathrm{O} \leftrightarrow \mathrm{CO}+\mathrm{H}_{2} \quad \Delta \mathrm{H}=+131 \mathrm{MJ} / \mathrm{kmol}$

c. Water gas shift :

$$
\mathrm{CO}+\mathrm{H}_{2} \mathrm{O} \leftrightarrow \mathrm{CO}_{2}+\mathrm{H}_{2} \quad \Delta \mathrm{H}=-41,98 \mathrm{MJ} / \mathrm{kmol}
$$

d. Methanation:

$$
\mathrm{C}_{(s)}+2 \mathrm{H}_{2} \leftrightarrow \mathrm{CH}_{4} \quad \Delta \mathrm{H}=-75 \mathrm{MJ} / \mathrm{kmol}
$$

e. Methane dry reforming:

$$
\mathrm{CH}_{4}+\mathrm{CO}_{2} \leftrightarrow 2 \mathrm{H}_{2}+2 \mathrm{CO} \Delta \mathrm{H}=+247 \mathrm{~kJ} / \mathrm{mol}
$$

f. Methane steam reforming:

$$
\mathrm{CH}_{4}+\mathrm{H}_{2} \mathrm{O} \leftrightarrow \mathrm{CO}+3 \mathrm{H}_{2} \quad \Delta \mathrm{H}=+206 \mathrm{~kJ} / \mathrm{mol}
$$


Jurnal Pengendalian Pencemaran Lingkungan (JPPL)

Vol.1 No.01 September 2019

Reaktor gasifikasi sendiri terdiri dari berbagai jenis. Perbedaan tersebut didasarkan pada interaksi yang terjadi antara udara dan bahan baku (Hitchon, 1996). Jenis-jenis reaktor tersebut adalah fixed-updraft, fixedbed downdraft atau co-current, fixed-bed crossdraft, dan fluidized bed gasifier. Namun saat ini, yang paling sering digunakan adalah tipe fixed-bed downdraft. Reaktor jenis ini paling banyak digunakan sebab menghasilkan kandungan tar yang lebih rendah dibandingkan tipe gasifier yang lainnya. Hal ini dikarenakan kandungan tar hasil pirolisis terbawa bersama gas dan kemudian masuk ke dalam proses oksidasi parsial sehingga kandungan tar dimungkinkan dapat terurai menjadi senyawa yang lebih ringan.

Tujuan dari penelitian ini adalah meneliti produksi hidrogen sebagai bahan bakar bersih melalui proses pirolisis berbahan baku limbah ampas tebu dengan melihat pengaruh perbedaan bentuk bahan baku (bentuk pellet dan serabut) dan perbedaan suhu gasifikasi (zona oksidasi pada suhu 800,950 , dan $1.050^{\circ} \mathrm{C}$ ). Hasil yang berupa gas sintetik akan dikarakterisasi dengan Gas Chromatography pada setiap variabel yang telah ditentukan.

\section{METODE PENELITIAN}

2.1. Waktu dan Lokasi Penelitian.

Penelitian yang dilakukan meliputi perangkaian alat dan persiapan bahan baku. Bahan baku yang berbentuk pellet terlebih dahulu dipelletkan hingga siap digunakan. Penelitian dilakukan dalam rentang waktu 6 bulan, yaitu sejak Juni hingga Desember 2016. Lokasi penelitian adalah di Laboratorium Penggilingan Lembaga Penelitian Perkebunan Yogyakarta.

\subsection{Alat dan Bahan Penelitian}

Alat yang digunakan dalam penelitian adalah reaktor gasifikasi berbentuk silinder dengan diameter dalam reaktor $20 \mathrm{~cm}$ sedangkan tingginya $80 \mathrm{~cm}$ seperti yang ditunjukkan oleh Gambar 1. Reaktor digunakan sebagai tempat berlangsungnya proses gasifikasi yang meliputi proses drying, pyrolysis, oxidation, dan reduction. Digunakan juga siklon utama sebagai penangkap debu yang terbawa oleh syngas yang keluar dari reaktor. Selain itu juga digunakan siklon pendingin sebagai pendingin syngas yang keluar dari siklon utama. Rangkaian alat juga ditambahkan selang polimer yang berfungsi sebagai penyalur syngas ke bagian pembakaran. Pada bagian bawa siklon pendingin dilengkapi dengan bak penampung black oil. Pada bagian ujung dilengkapi dengan pompa untuk menarik syngas dan sekaligus sebagai penarik oksigen yang masuk ke reaktor. Yang terakhir digunakan adalah botol vacutainer untuk menampung syngas yang akan dikarakterisasi. Juga digunakan syringe untuk mengambil dan mamasukkan syngas ke vacutainer. Pada bagian pendeteksi suhu digunakan 4 buah thermocouple untuk mendeteksi suhu pada setiap area proses gasifikasi pada reaktor, yaitu pada daerah drying, pyrolysis, oxidation, dan reduction. Karakterisasi syngas yang digunakan adalah GC. 
Jurnal Pengendalian Pencemaran Lingkungan (JPPL)

Vol.1 No.01 September 2019

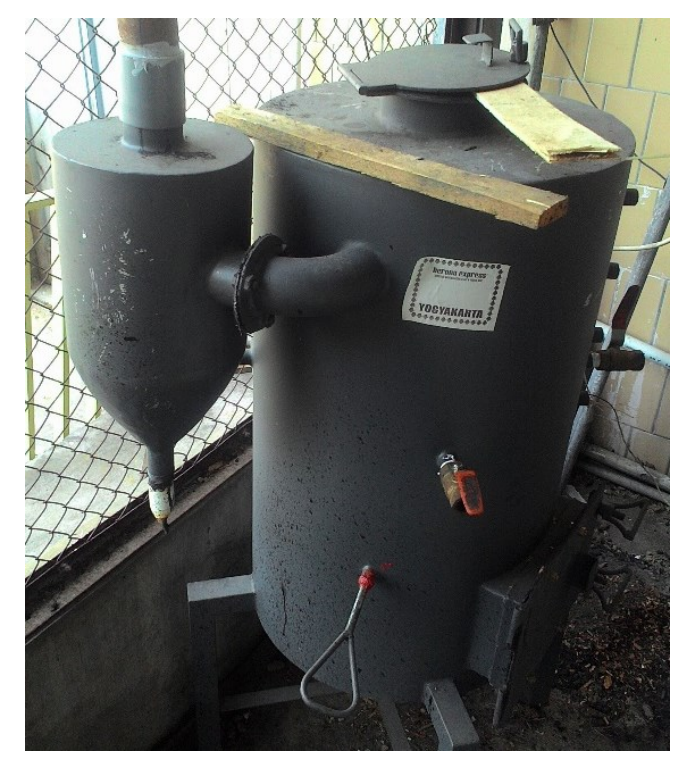

Gambar 1. Reaktor Gasifikasi

Bahan yang diguanakan dalam penelitian ini adalah ampas tebu yang diambil dari PT. Perkebunan Nusantara X. Ampas tebu sebagai bahan baku divariasikan dalam 2 bantuk, yaitu pellet dengan diameter $6 \mathrm{~mm}$ dan panjang $5 \mathrm{~cm}$, dan juga dalam bentuk serabut. Hasil uji proximate dan ultimate bahan baku dapat dilihat pada Table 1.

Tabel 1. Hasil Uji Proximate dan Ultimate Ampas Tebu

\begin{tabular}{lllll}
\hline NO & Proximate Analysis & (\%berat) & Ultimate Analysis & (\%berat) \\
\hline 1. & Fixed Carbon & 7 & Karbon $(\mathrm{C})$ & 23,7 \\
2. & Volatile Matters & 42,5 & Hidrogen $(\mathrm{H})$ & 3,0 \\
3. & Moisture & 49 & Oksigen $(\mathrm{O})$ & 22,8 \\
4. & Ash & 1,5 & Moisture $\left(\mathrm{H}_{2} \mathrm{O}\right)$ & 49 \\
5. & & & Ash & 1,5 \\
\hline
\end{tabular}

2.3. Prosedur Penelitian.

Penelitian dilakukan dengan memasukkan bahan baku ke dalam reaktor. Pompa yang berada pada bagian depan dihidupkan agar suplai oksigen terpenuhi. Selanjutnya bahan baku dibakar sekaligus thermocouple dihidupkan. Ketika suhu mencapai suhu yang telah ditentukan, syngas yang keluar dari arah ujung dibakar agar diketahui bahwa syngas telah terbentuk. Ketika mencapai suhu yang diinginkan, yaitu 800, 950, dan $1.050^{\circ} \mathrm{C}$, syngas yang melewati selang polimer diambil dengan menggunakan syringe dan dimasukkan ke dalam vacutainer untuk dikarakterisasi menggunakan GC. Hal serupa juga dilakukan pada variabel perbedaan jenis bahan baku, yaitu pellet dan serabut. Rangkaian alat gasifikasi dapat dilihat pada Gambar 2.

Setelah hasil karateristik diketahui, maka penelitian dilanjutkan dengan membuat grafik antara perbedaan suhu dan bentuk bahan baku terhadap kompoisis gas $\mathrm{H}_{2}$ dan $\mathrm{CH}_{4}$ pada bagian produk sekaligus melihat nilai hydrogen conversion efficiency (HCE) yang dihasilkan. Rumus hydrogen conversion efficiency yang digunakan adalah seperti yang diperlihatkan pada Persamaan 8 .

$H C E=\frac{\text { Hydrogen pada syngas }}{\text { Hydrogen pada bahan baku }} \times 100 \%$ 


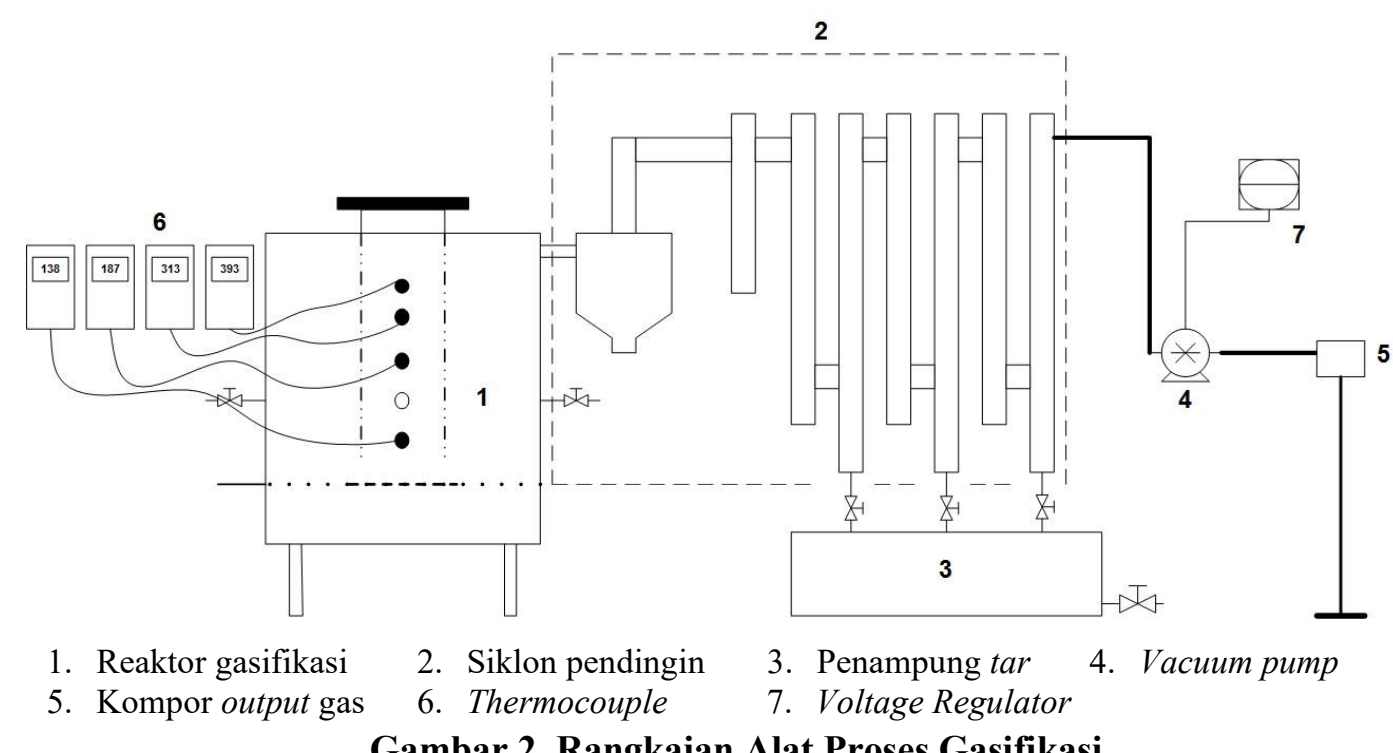

Gambar 2. Rangkaian Alat Proses Gasifikasi

\section{HASIL DAN PEMBAHASAN.(12 pt, Times New Roman, Bold)}

3.1. Hasil Komposisi $\mathrm{H}_{2}$

Nilai komposisi $\mathrm{H}_{2}$ dalam produk syngas pada penelitian ini dapat dilihat pada Gambar 3. Nilai ini menunjukkan seberapa besar $\mathrm{H}_{2}$ sebagai produk bersih dapat dihasilkan melalui gasifikasi biomassa ampas tebu.

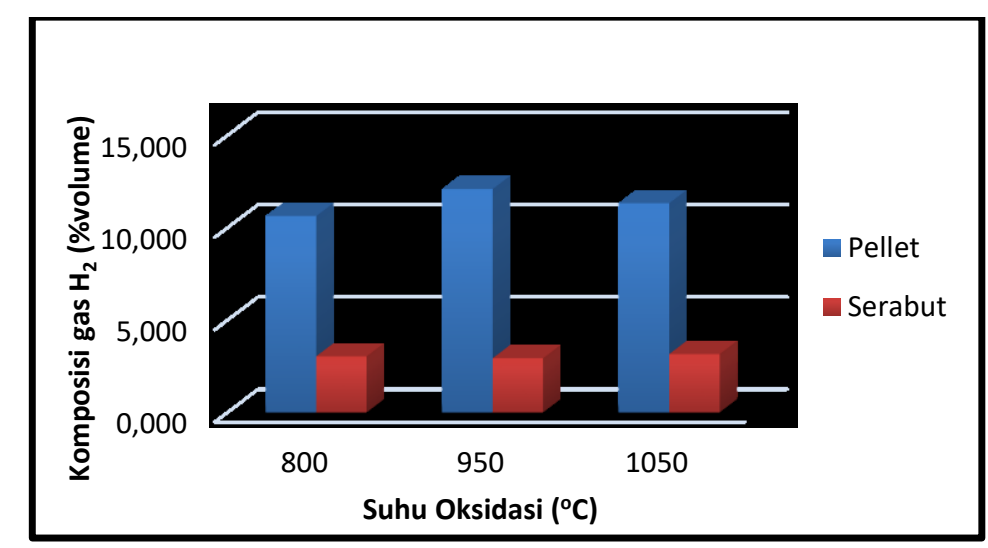

Gambar 3. Komposisi Gas $\mathrm{H}_{2}$ dalam Produk Syngas

Dari Gambar 3 dapat dilihat bahwa terjadi kecendrungan peningkatan kadar $\mathrm{H}_{2}$ yang terbentuk berdasarkan peningkatan suhu baik untuk bahan baku berbentuk pellet maupun serabut. Walaupun peningkatan tidak terlalu besar, bahkan realtif stagna. Komposisi $\mathrm{H}_{2}$ yang didapatkan pada suhu 800, 950, dan $1050^{\circ} \mathrm{C}$ untuk bentuk pellet berturut-turut adalah 10,618, 12,080, dan 11,312\%volume. Sedangkan untuk bentuk serabut pada suhu yang sama berturut-turut adalah 3,025, 2,925, dan 3,150\%volume. Hasil pada variasi suhu ini sejalan dangan hasil yang didapatkan oleh Hernandez dkk. (2010), dimana terjadi peningkatan komposisi $\mathrm{H}_{2}$ pada syngas yang tidak begitu signifikan dengan adanya peningkatan suhu gasifikasi. Hal ini kemungkinan disebabkan karena terjadinya pembentukan $\mathrm{H}_{2}$ pada zona reduksi yaitu pada reaksi water-gas, reaksi methane dry reforming, dan methane steam reforming yang merupakan reaksi endotermik. Sehingga 
Jurnal Pengendalian Pencemaran Lingkungan (JPPL)

Vol.1 No.01 September 2019

dengan adanya peningkatan suhu, reaksi tersebut akan semakin cepata dan kuat (Rodrigues dkk., 2017). Namun dengan adanya reaksi $\mathrm{H}_{2}$ dan Oksigen pada zona oksidasi menyebabkan terjadinya pembentukan $\mathrm{H}_{2} \mathrm{O}$ secara simultan sehingga terjadi penurunan kadar $\mathrm{H}_{2}$ pada suhu $1050^{\circ} \mathrm{C}$ untuk bahan baku berbentuk pellet. Pada perbedaan bentuk bahan baku ampas tebu, terjadi penurunan komposisi $\mathrm{H}_{2}$ yang sangat signifikan, ketika bahan baku diri bentuk pellet menjadi bentuk serabut. Hal ini kemungkinan terjadi karena konsumsi karbon untuk bahan baku pellet lebih besar dibandingkan serabut dalam jangka waktu yang bersamaan. Hal ini dapat dijelaskan dengan persamaan water-gas, dimana pembentukan $\mathrm{H}_{2}$ pada bentuk pellet jauh lebih besar daripada bentuk serabut.

\subsection{Produk Hidrogen yang terdapat pada Senyawa $\mathrm{CH}_{4}$}

Pengaruh perbedaan bahan baku dan suhu terhadap hidrogen yang dihasilkan dapat juga dilihat

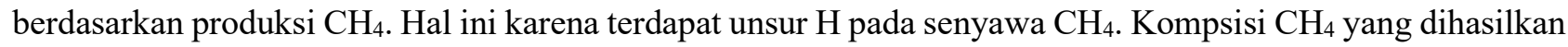
dapat dilihat pada Gambar 4.

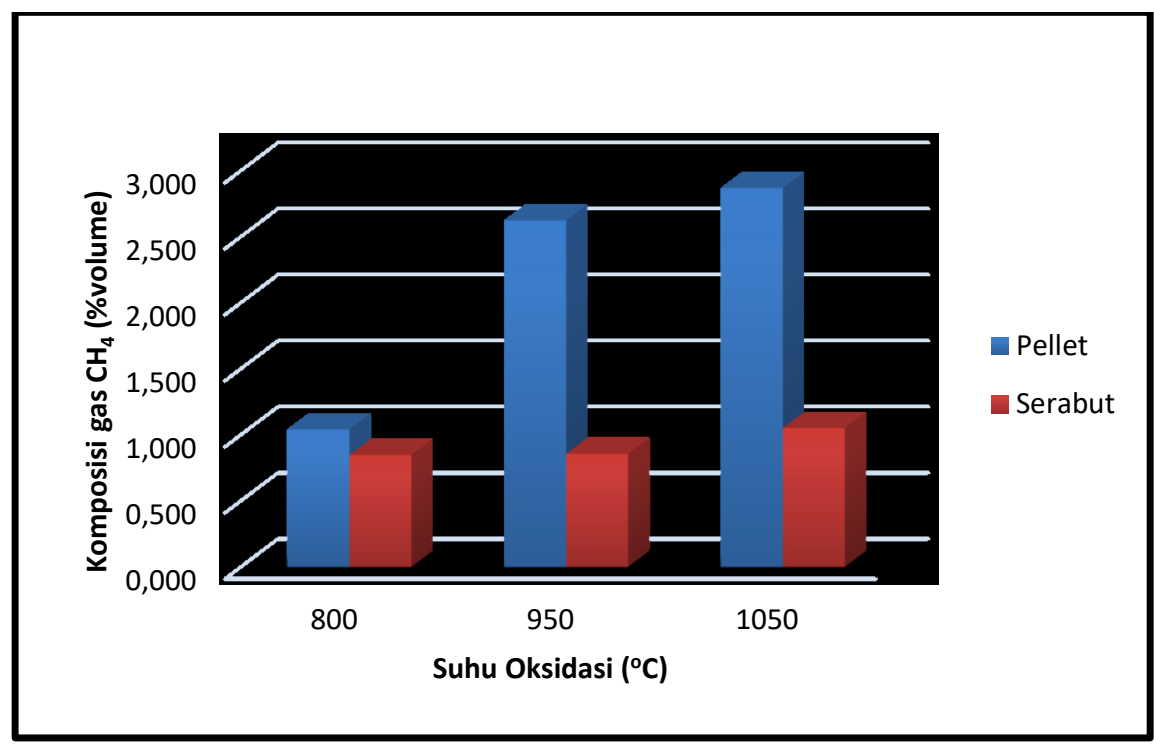

Gambar 4. Komposisi $\mathrm{CH}_{4}$ pada Produk Syngas

Pada Gambar 4 memperlihatkan peningkatan komposisi $\mathrm{CH}_{4}$ pada syngas dengan meningkatnya suhu gasifikasi, baik untuk bahan baku berbentuk pellet maupun serabut. Hal ini sejalan dengan penelitian yang dilakukan oleh Rodrigues dkk. (2017). Pada penelitiannya memperlihatkan peningkatan komposisi gas $\mathrm{CH}_{4}$ dari suhu $780-850^{\circ} \mathrm{C}$. Hal ini kemungkinan disebabkan karena factor kenetika yang terjadi pada proses gasifikasi terutama untuk reaksi methanation, sebab semakin tinggi suhu, maka pembentukan produk syngas menjadi lebih banyak dan cepat (Lahijani dan Ainal, 2011). Untuk perubahan bentuk bahan baku dari pellet ke serabut, komposisi $\mathrm{CH}_{4}$ mengalami penurunan yang signifikan, hal ini kemungkinan disebabkan karena reaksi methanation pada bahan baku berbentuk pellet lebih baik, sebab karbon yang digunakan lebih besar. Komposisi $\mathrm{CH}_{4}$ yang didapatkan pada suhu 800,950 , dan $1050^{\circ} \mathrm{C}$ untuk betuk pellet berturut-turut adalah $1,040,2,622$ dan 2,867\%volume. Sedangkan untuk bentuk serabut pada suhu yang sama berturut-turut adalah $0,846,0,856$, dan $1,051 \%$ volume.

\subsection{Hydrogen Conversion Efficiency (HCE)}


Jurnal Pengendalian Pencemaran Lingkungan (JPPL)

Vol.1 No.01 September 2019

Nilai HCE pada penelitian ini dapat dilihat pada Gambar 5. HCE diunakan untuk melihat seberapa besar hidrogen yang terkonversi dari bahan baku. Dan dari penelitian ini dapat dilihat pengaruh peningkatan suhu dan perubahan bentuk bahan baku ampas tebu terhadap nilai HCE yang dihasilkan.

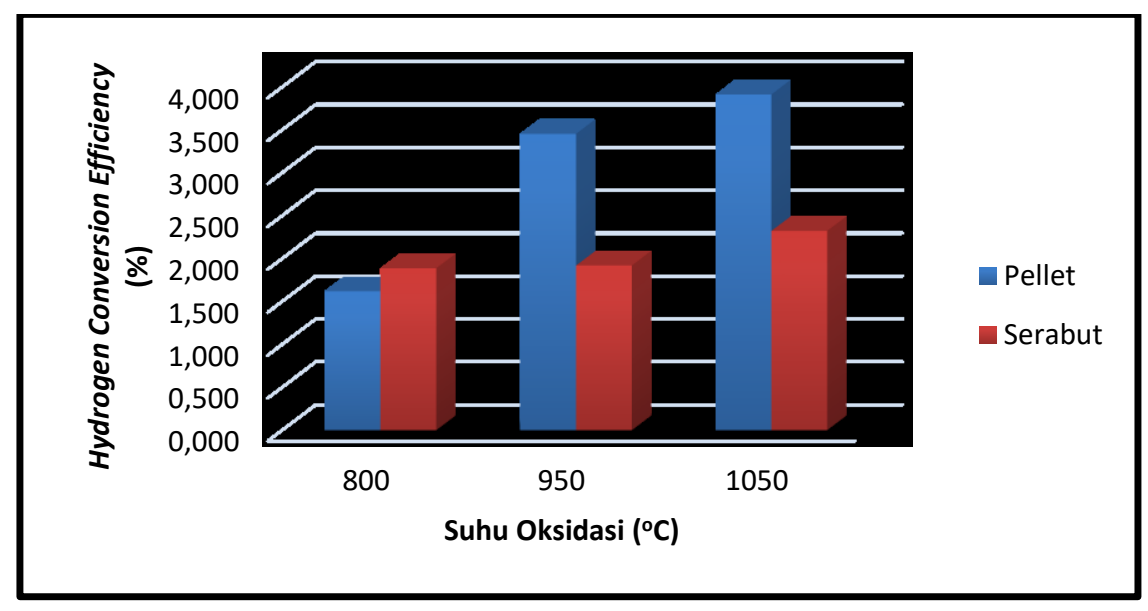

Gambar 5. Nilai HCE Gasifikasi

Dari Gambar 5 dapat dilihat bahwa terjadi peningkatan nilai HCE dengan meningkatnya suhu gasifikasi baik untuk ampas tebu berbentuk pellet maupun serabut. Nilai HCE yang didapatkan pada suhu 800, 950, dan $1050^{\circ} \mathrm{C}$ untuk bentuk pellet berturut-turut adalah 1,617, 3,452 dan 3,910\%volume. Sedangkan untuk bentuk serabut pada suhu yang sama berturut-turut adalah 1,885, 1,918, dan 2,320\%volume. Hasil ini sejalan dengan Seikhdavodi dkk. (2015). Hasil ini kemungkinan terjadi karena suhu yang lebih tinggi mendorong reaksi pembentukan metana untuk meningkatkan hasil hidrogen (Amrullah dkk., 2017). Penambahan ini dapat dijelaskan melalui reaksi water-gas, methane steam reforming, dan methane dry reforming. Pada reaksi-reaksi tersebut terjadi reaksi endotermik yang apabila suhu meningkat, maka reaksinya akan berjalan secara terus menerus dan maksimal pada waktu yang singkat. Alasan lain adalah adanya reaksi yang meningkat dari reaksi water-gas shift dimana air pada keadaan superheated tidak hanya bertindak sebagai media tetapi juga sebagai reaktan (Jarana dkk., 2008). Faktanya, air yang dipanaskan dapat menghasilkan atom hidrogen dan hidrogen yang terbentuk melalui reaksi water-gas shift ini selanjutnya dapat bereaksi dengan zat antara lainnya (Kruse dkk., 2010). Hidrogen reaktif ini juga dapat membantu menghentikan reaksi radikal bebas yang akhirnya mengurangi pembentukan spesies dengan berat molekul lebih tinggi dan akhirnya menghasilkan lebih banyak pembentukan gas hidrogen. Sedangkan untuk perubahan bentuk bahan baku, terjadi penurunan nilai HCE ketika bahan baku ampas tebu dirubah dari bentuk pellet kebentuk serabut. Hal ini disebabkan karena terjadi peningkatan konsumis karbon ketika menggunakan bahan baku berbentuk pellet. Hal ini dapat dijelasan menggunakan reaksi water-gas, dimana pada reaksi tersebut terjadi reaksi karbon dan air menjadi karbon monokida dan gas hidrogen (Rodregues dkk., 2017).

\section{KESIMPULAN DAN SARAN}

Kesimpulan dari penelitian ini adalah, terjadi peningkatan komposisi hidrogen dalam gas $\mathrm{H}_{2}$ untuk peningkatan suhu gasifikasi, baik pada bentuk bahan baku ampas tebu berupa serabut maupun pellet. Hal ini 
Jurnal Pengendalian Pencemaran Lingkungan (JPPL)

Vol.1 No.01 September 2019

terjadi karena adanya pembentukan $\mathrm{H}_{2}$ yang semakin besar untuk suhu yang lebih tinggi pada reaksi watergas, reaksi methane dry reforming, dan methane steam reforming yang merupakan reaksi endotermik. Selain itu terjadi penurunan kadar hidrogen pada gas $\mathrm{H}_{2}$ ketika bahan baku dirubah dari bentuk pellet ke bentuk serabut. Hal ini berdasarkan persamaan water-gas, dimana karbon yang digunakan pada bentuk pellet lebih besar. Komposisi $\mathrm{H}_{2}$ yang didapatkan pada suhu 800 , 950, dan $1050^{\circ} \mathrm{C}$ untuk betuk pellet dan serabut berturutturut adalah 10,618, 12,080,11,312\%volume, dan 3,025, 2,925, dan 3,150\%volume.

Hidrogen yang berada pada senyawa $\mathrm{CH}_{4}$ mengalami peningkatan dengan meningkatnya suhu gasifikasi baik untuk bentuk bahan baku pellet maupun serabut, yaitu 1,617, 3,452, 3,910\%volume untuk pellet dan $1,885,1,918$, dan $2,320 \%$ volume untuk serabut pada suhu 800,950 , dan $1050^{\circ} \mathrm{C}$. Hal ini kemungkinan disebabkan karena factor kenetika yang terjadi pada proses gasifikasi terutama untuk reaksi methanation, dimana semakin tinggi suhu, maka pembentukan produk syngas menjadi lebih banyak dan cepat. Sedangkan Untuk perubahan bentuk bahan baku dari pellet ke serabut, komposisi $\mathrm{CH}_{4}$ mengalami penurunan yang signifikan, hal ini kemgungkinan disebabkan karena reaksi methanation pada bahan baku berbentuk pellet lebih baik, sebab karbon yang digunakan lebih besar.

Nilai HCE pada penelitian ini memperlihatkan peningkatan dengan peningkatan suhu gasifikasi, baik untuk bentuk pellet maupun serabut. Nilai yang didapatkan adalah 1,617, 3,452, 3,910\%volume untuk pellet dan $1,885,1,918$, dan 2,320\%volume untuk serabut pada suhu 800,950 , dan $1050^{\circ} \mathrm{C}$. Hasil ini kemungkinan terjadi karena suhu yang lebih tinggi mendorong reaksi pembentukan metana untuk meningkatkan hasil hidrogen. Hal ini dapat dijelaskan dengan reaksi water-gas, methane steam reforming, dan methane dry reforming, dimana reaksi-reaksi tersebut terjadi secara endotermik. Sedangkan untuk perubahan bentuk bahan dari pellet ke serabut mengakibatkan nilai HCE menurun. Hal ini kemungkinan disebabkan karena terjadi peningkatan konsumis karbon ketika menggunakan bahan baku berbentuk pellet, hal ini dapat dijelasan menggunakan reaksi water-gas.

\section{UCAPAN TERIMA KASIH}

Diucapkan terimakasih kepada Prof. Ir. Arief Budiman dan keluarga besar Pusat Studi Energi, Universitas Gadjah Mada Yogyakarta yang telah membantu dalam hal illmu dan pendanaan. Terimakasih juga untuk Lembaga Penelitian Perkebunan yang telah sedia meminjamkan Laboratorium sebagai tempat dilaksanakannya penelitian ini. Selain itu, saya ucapkan terimakasih juga untuk pak Dr. Hendriyana, S.T., M.Eng. yang telah mengajarkan sistem operasional gasifikasi.

\section{DAFTAR PUSTAKA}

Amrullah, S., Perdan, I., \& Budiman, A. (2017). Study on Performance and Environmental Impact of Sugarcane-Bagasse Gasification. In Joint International Conference on Science and Technology in the Topic (pp. 121-127). Mataram, Indonesia: University of Mataram, University of Malaya, Indonesia. 
Jurnal Pengendalian Pencemaran Lingkungan (JPPL)

Vol.1 No.01 September 2019

Balat, M., Kırtay, E., \& Balat, H. (2009). Main Routes for the Thermo-Conversion of Biomass into Fuels and Chemicals. Part 2: Gasification Systems. Energy Conversion and Management, 50, 3158-3168.

Fledmann. (2008). Biomass Gasification System. Us Patent Application, US 2008/0022592A1.

Freitas, A. C. D. \& Guirardello, R. (2015). Use of $\mathrm{CO}_{2}$ as A Co-Reactant to Promote Syngas Production in Supercritical Water Gasification of Sugarcane Bagasse. Journal of $\mathrm{CO}_{2}$ Utilization, 9, 66-73.

Herlambang, A., Amrullah, S., Daniyanto, D., Pradana, Y.S., Rochmadi, \& Budiman, A. (2018). Biomass pretreatment on non-catalytic gasification of Indonesian sugarcane bagasse. AIP Conference Proceedings 2026, 020032. Indonesia.

Hernandez, J. J., Arnanda-Almansa, G., and Bula, A. (2010). Gasification of Biomass Wastes in An Entrained Flow Gasifier: Effect of The Particle Size and The Residence time. Fuel Processing Technology, 92, 681-692.

Hitchon, B. (1996). Aquifer Disposal of Carbon Dioxide: Hydrodynamic and Mineral Trapping-Proof of Concept, Geoscience Publishing, Alberta, Canada.

Jarana, M.B.G., Sanchez-Oneto, J., \& Portela, J.R. (2008). Supercritical water gasification of industrial organic wastes. Journal of Supercritical Fluids, 46, 329-334.

Kruse, A., bernolle, P., Dahmen, N., Dinjus, E., \& maniam, P. (2010). Hydrothermal gasification of biomass: consecutive reactions to long-living intermediates. Royal Society of Chemistry, 3, 136-143.

Lahijani, P. \& Ainal, Z.A. (2011). Gasification of palm empty fruit bunch in a bubbling fluidized bed: a performance and agglomeration study, Bioresource Technology, 102 (2), 2068 - 2076.

Rajvanshi, A. K. (1986), BIOMASS GASIFICATION. Nimbar Agricultural Research Institute, Maharashtra, India.

Rodrigues, S., Almeida, A., Ribeiro, A., Neto, P., Ramalho, E., \& Pilao, R. (2017). Influence of temperature on the gasification of cork wastes. Energy Procedia, 136, 127-132.

Sarker, S., Arauzo, J., \& Nielsen, H. K. (2015). Semi-Continuous Feeding and Gasification of Alfalfa and Wheat Straw Pelets in A Lab-Scale Fluidized Bed Reactor. Energy Conversion and Management, 99, 50-61.

Seikhdavoodi, M.J., Almassi, M., Ebrahimi-Nik, M., Kruse, A., \& Bahrami, H. (2015). Gasification of sugarcane bagasse in supercritical water; evaluation of alkali catalysts for maximum hydrogen production. Journal of Energy Institute, 88, 450-458.

World Energy Outlook 2013 Factsheet (2013). How Will Global Energy Markets Evolve To 203, Paris, France: International Energy Agency.

Yaman, S. (2004). Pyrolisys of Biomass to Produce Fuels and Chemical Feed Stocks. Energy Conversion and Management, 45, 651-671. 